\title{
In defence of administrative criminology
}

CrossMark

Pat Mayhew*

\begin{abstract}
Background: This paper is based on an address given as joint winner with Ronald V. Clarke of the 2015 Stockholm Prize in Criminology. This was awarded for some early studies we worked on together in the UK Home Office which were seen as important in re-focusing the task of preventing crime towards simply reducing opportunities for it. This approach became known as situational crime prevention. It had a hostile academic reception from academic criminologists and earned the label of 'administrative criminology'. Later, the same label was given to what was portrayed as narrow, unscholarly research done for government to serve their political agenda, in contrast to research with more range and theoretical thrust. Administrative criminology is a term most familiar in relation to UK research supported by its government; this is the paper's context.
\end{abstract}

Discussion: Administrative criminology deserves a much more positive appraisal than it has been given to date. First, government research activity through to the 1990s at least was self-generated (not imposed), was influential, and was often controversial. The research establishing situational crime prevention as a generally effective approach has withstood criticism that it lacks intellectual weight and would not work. Second, administrative criminologists have been consistently brought to heel as regards ensuring that they communicate what they know effectively and clearly. Third, administrative criminology has arguably had more influence on policy than academic criminology, since its business is to address the concerns of government to which it is better placed to make its voice heard. Finally, administrative criminology should be credited for keeping the 'criminological ball rolling' insofar as it provides a wealth of data from expensive surveys on victimisation and offending, as well as basic 'facts and figures' from statistical series on crime and the criminal justice system. These data serve criminologists of all complexions.

Summary: This paper discusses the two fronts on which administrative criminology has been criticised. It defends its record on both fronts. It also argues that critics overlook the contribution that administrative criminology makes to supplying much of the basic empirical data on which all criminologists draw.

Keywords: Administrative criminology, Situational crime prevention, Home Office research, British crime Survey, Crime reduction programme

\section{Background}

This paper is based on the address I gave on receiving the 2015 Stockholm Prize in Criminology, awarded jointly with Ronald V. Clarke (School of Criminal Justice, Rutgers University). The prize recognised a series of studies on which we worked together in the 1970s and 1980s in the UK Home Office. ${ }^{1}$ These were seen as important in re-focusing the task of preventing crime towards reducing and manipulating opportunities for it, rather than trying to change people's disposition to offend, or reform

*Correspondence: mayhew3@btinternet.com Ex-Research, Development and Statistics Directorate, UK Home Office, 17 Ashchurch Terrace, London W12 9SL, UK known offenders. These studies formed the basis of what became known as situational crime prevention (SCP) an approach that first attracted the label 'administrative criminology'. The term now, though, is more widely used to cover what is seen as atheoretical, narrowly focussed research done within or for government within tight confines of the current political agenda. This paper mounts a

\footnotetext{
${ }^{1}$ Until 2007, the Home Office had an amalgam of responsibilities, which included policing, the penal system, and the criminal law-but not the courts and the judiciary. In 2007, the Home Office was split into two with a new Ministry of Justice subsuming the Departmental of Constitutional Affairs to take responsibility for prisons, probation and sentencing. The Home Office now deals with crime, policing, terrorism, security and immigration.
} 
defence of administrative criminology in both guises. It also argues for a widening of the concept of administrative criminology.

Administrative criminology may be a term unfamiliar to many readers. It may be recognised by others who, while they have no clear sense of its meaning, are cognisant that it is nearly always referred to negatively. It is most often used in the UK, and my defence of administrative criminology is thus set in a UK context. ${ }^{2}$ I mount my defence as someone who sees herself as a quintessential administrative criminologist. Most of my career was as a Home Office researcher, but three periods of work elsewhere were all in essentially administrative criminology environments: in the late 1980s at the National Institute of Justice (NIJ), the research arm of the US Department of Justice; between 2001 and 2003 at the Australian Institute of Criminology (a statutory authority geared to undertaking and communicating evidence-based research); and between 2004 and 2008 at Victoria University of Wellington in New Zealand where I headed the Crime and Justice Research Centre which did applied research under grants largely from government departments or the police.

As said, the term administrative criminology was first attached to SCP, which was chastised, amongst other things, as wilfully ignoring the 'root causes' of crime. The term was first coined by Jock Young in a 1986 essay (Young 1986). He skirted a definition of administrative criminology, talking instead about a reconstitution of 'establishment' criminology in the USA and particularly within the Home Office. Young certainly singled out Ron Clarke, but it was later textbooks that explicitly defined administrative criminology as being SCP and the 'rational choice' theory that Clarke developed alongside it (see, for example, McLaughlin 2006; Tierney 2009). As said, though, administrative criminology has now lost its mooring to SCP. For its critics now, it is seen as Hirschi (1993) describes it: a poor specimen of research and thinking consistent with requirements of government bureaucrats.

In this paper I take up first the development of SCP in the mid-1970s in the Home Office Research Unit, as well as other work that transformed thinking about the delivery of crime prevention. The examples taken here are policing research and the British Crime Survey. ${ }^{3}$ I will then look at changes that altered the complexion of administrative criminology, and the nature of the new criticisms against it. Changing tack a little, I then touch on some matters to do with research communication and

\footnotetext{
${ }^{2}$ Strictly speaking, I am talking about England and Wales, but 'UK' is simpler. Scotland and Northern Ireland had their own, smaller research capabilities. I would imagine much of what I say would apply across the borders.

3 The BCS was renamed the Crime Survey for England and Wales in 2012 when management of the survey transferred from the Home Office to the Office of National Statistics. I will use BCS for old times' sake however.
}

influence, and how I see administrative criminology as fitting in here.

I propose that administrative criminology deserves a much more positive appraisal than it has been given to date. To anticipate what follows, SCP (and much other government research activity in the UK in the 1960s through to the 1990s) was largely self-generated rather than imposed; it was influential and often controversial. In-house government researchers were competent (testified by the fact that many now hold several of the senior academic posts in universities), and were happy to prioritise the task of informing policy over that of extending esoteric academic debate. They were also brought to heel as regards ensuring that what they knew was effectively and clearly communicated. After the turn of the century, a number of changes in the organisation of research in the Home Office, including control of the research budget being moved from researchers to policy divisions, substantially increased the influence the policy centre had on the nature of research to be supported, and weakened professional links between in-house researchers and outside academics. Relationships were also fractured by the burden of evaluating the huge, ill-fated 1999 Crime Reduction Programme. Further strains came from having research resources diverted to simply measuring whether targets imposed by Performance Management were being met. However, I will argue that any recent 'watering down' of administrative criminology says more about increasing managerialism and accountability at the policy centre than what can be delivered in a more benign research environment. Finally, I suggest that administrative criminology should be credited for work that 'keeps the criminological ball rolling' in other ways. For instance, it provides important knowledge from expensive, government-funded data-gathering exercises such as victimisation or offender surveys. I also see it as encompassing the collection of essential routine administrative, statistical data (the number of people arrested, the number taken to court, etc.), which critics of administrative criminology seem to put in the firing line alongside research under an administrative criminology banner. ${ }^{4}$

\section{The Home Office Research Unit}

Ron Clarke and I joined the Home Office Research Unit in the late 1960s as it was growing into the biggest centre of criminological research in the UK, both in terms of the research it did itself and which it funded. It had a strong international reputation. The Unit had substantial control

\footnotetext{
${ }^{4}$ In the UK, statistical series are delivered alongside research. Arrangements may differ elsewhere, with different agencies involved-but still serving government.
} 
over both the internal and external research programme. As a 'standalone' unit, its researchers saw themselves as rather distant from policy; Hough (2014: 218) described us as "rather reluctant civil servants". Any notion that we were administrative lackeys is rather misplaced. On the whole, there was a healthy professional relationship between us in our concrete towers and outside academics in their ivory ones. (They were, of course, conscious of the fact that we held the strings of a large purse.) Good relationships were helped by a commitment to publication, and the fact that the Home Office Research Programme was published, and academics were brought into comment on it.

The late 1970s, however, saw a fracturing of the criminological community. On one side were the traditional 'positivists' that government criminologists were seen to represent and favour. Poles apart were the emergent radical criminologists who wanted to reframe the crime control debate entirely-in particular to look at its sociological and political underpinnings (e.g., Taylor et al. 1973). It was mainly from within these ranks that the first assault on administrative criminology was mounted.

\section{The development of situational crime prevention}

Much research in the Home Office when Ron Clarke and I joined it was about the causes of offending, and the effectiveness of different interventions in rehabilitating offenders. Clarke strongly disagreed with the notion that some people are simply 'disposed' to criminalitythrough genetics, personality, or poor upbringing (for an early discussion, see Clarke 1980). Nor did he think that looking at different criminal sanctions was fruitful. Clarke was not entirely on his own. The message coming from North America was that 'nothing works' (Martinson 1974). In the Research Unit, a report on the effectiveness of sentencing reached the same conclusion (Brody 1976). This was a serious 'wobble', leaving a policy vacuum that some other approach could potentially fill. SCP was a contender. ${ }^{5}$ It distinguished itself from 'social' prevention' aimed at addressing possible criminogenic factors such as poverty, unemployment, or poor education. What it was interested in basically was not why people offended, but the situations in which they offended, and how these situations could be acted upon to increase the risks and reduce the gains. An underlying principle was that situational measures needed to be directed at

\footnotetext{
${ }^{5}$ Actually, Ron Clarke lays no claim to inventing the terms situational crime prevention. We think it was invented by a policy unit in the late $1970 \mathrm{~s}$. Before that, the term used was 'physical' crime prevention-for instance, in Crime as Opportunity (Mayhew et al. 1976). It was also sometimes called 'environmental' crime prevention.
}

specific forms of crime based on a thorough understanding of the circumstances that encouraged them.

Looking back, some of the first SCP studies concerned with assessing the role of opportunity and situation in crime seem rather 'quaint.' (For example, one study looked at the effect of motorcycle helmet legislation on motorcycle theft; another at whether the introduction of steering column locks reduced theft of cars; another at how having conductors on buses influenced where vandalism occurred on the bus). However, there have been many more subsequent studies, and the initial typology of eight SCP measures has now expanded to 25 (see Cornish and Clarke 2003). A few of the subsequent studies were done in the Home Office after Ron Clarke left, although SCP work in the UK has now mainly been incorporated into the 'crime science' promoted by Jill Dando Institute (see Tilley and Laycock 2007) - the new bête noire for academic criminologists.

\section{Reactions}

The early SCP work played to a sceptical government audience who did not much care for Clarke's rationale that situational factors in crime commission were eminently more manipulable than social factors and that we should simply look at these. ${ }^{6}$ Outside academics were negative too. They saw the government as turning to SCP as a last resort-ignoring the fact that government was yet to be convinced. Wortley (2010) lists the criticisms of SCP: it was simplistic; it ignored underlying social and cultural causes of crime; it lacked theoretical sophistication; it would merely displace crime in time, place or form; it assumed offenders were rational actors; and it would lead to a 'fortress society'. The criticisms came from several fronts, though most vocally from the more radical criminologists. All the criticisms have been robustly challenged (see, for example, Clarke 2005), and that rebuttal is not my concern here. Rather, I move onto the next developments to argue that it was criminology done and funded by government, rather than that coming from elsewhere that exerted most influence. I will focus briefly on: (i) the British Crime Survey; and (ii) the development of policing research.

\section{The British Crime Survey}

As said, I put large-scale victimisation and self-reported offending surveys firmly under the banner of administrative criminology, and Matthews (2014) had the British Crime Survey (BCS) clearly in his sights. The first sweep

\footnotetext{
${ }^{6}$ In the US, James Q. Wilson was the devil incarnate. Thinking about Crime (Wilson 1975) argued much the same case, with particular emphasis put on more effective modes of policing.
} 
of the BCS was in 1982, by which time the Research Unit had become the Research and Planning Unit (RPU). The survey was a substantial administrative criminology project in its own right. It was sold by researchers to policy divisions who were not enthusiastic in the early days. It aligned with SCP interests in various ways. For one, it showed the crime problem as it actually affected householders rather than as documented in police-recorded crime. Second, it identified the important phenomenon of repeat victimisation, which generated a number of studies in the SCP mould. Third, it tracked how targets of theft changed over time, showing how simple availability and desirability of targets could determine crime patterns. Fourth, it revealed just how much ordinary crime stays beyond the reach of the criminal justice system, by not being reported to the police, by not always being recorded by them, by not being cleared up, etc. At the same time, the BCS also showed how risks of victimisation varied in ways that implicated social and economic factors - so not quite on the SCP agenda.

The BCS has now run now for over 30 years (see Hough and Maxfield 2007 for a discussion). Let me just highlight the fact that the survey has provided-out of the administrative criminology stable-a wealth of data on the nature, level and distribution of victimisation risk, as well as on a huge range of other crime-related topics. These data can serve a diverse set of criminological interests, and we encouraged and funded the use of the survey for these.

\section{Policing research}

In the early 1980s, Ron Clarke started a number of studies of the police which bought more 'bad news', seriously challenging the value of traditional policing and simply putting 'more police on the ground' (Clarke and Hough 1980, 1984). This led Clarke to promote what he called 'situational policing. This was akin to problem-oriented policing being developed by Herman Goldstein in the US at same time to sharpen police practices in relation to specific forms of crime, using more analytic and focussed thinking. As those in the UK tended to be rather overawed by American developments, situational policing got a bit of a wind behind it. Research was taken forward most actively by researchers in a new Crime Prevention Unit set up within the Police Department in the early 1980s, which later became the Police Research Group, headed by Gloria Laycock. ${ }^{7}$ These administrative crimi-

\footnotetext{
${ }^{7}$ Policing research continued to an extent in RPU itself after Ron left in 1984. The PRG was closed down in 2002, as research resources were 'streamlined.' Later, policing research in the Home Office emerged actively again but largely with an emphasis on improving confidence in the police, through 'reassurance' and neighbourhood policing for instance.
}

nologists produced an impressive amount of influential research.

\section{Change in the delivery of crime prevention}

Various research strands, then, had brought rather unwelcome news, showing the limits of traditional policing, and the small number of offenders captured by the criminal justice system, which did not do very well in preventing re-offending anyway. An important outcome of this was to cement the idea that to reduce crime one needed to look beyond sanctions and to share the burden of prevention between the police, local agencies, businesses and the public-all working in partnership. ${ }^{8}$

Without dwelling on the series of important developments (some placed in statute) to which this change of thinking led, suffice it to say just two things. First, the job of monitoring partnership working-which was by no means easy-fell largely to those servicing administrative criminology in the Home Office (see, for example, Liddle and Gelsthorpe 1994; Sutton 1995). Second, by the turn of the century, SCP and 'designing out crime' were ideas that thoroughly permeated the work of the new 'community safety' partnerships.

\section{Other work}

I should not give the impression that it was only policing work and the BCS that was going on. There was an eclectic programme of other work. Research continued on the operation and effects of different sanctions; race and crime began to merge as an issue, as did drugs and crime. There were other surveys started-for instance, the first sweep of the Commercial Victimisation Survey was in 1994, the Youth Lifestyles Survey started a year earlier, and the offending, crime and justice survey started in 2003.

Moreover, the Home Office was managing a variety of statistical series. The largest of these related to policerecorded crime, and sentencing outcomes. But there were others (for instance, on the prison population, reconviction rates, complaints against the police, drug seizures and drug offenders, and motoring offences). All this was administrative criminology; and it was of course empirical fodder for criminologists in all their different stripes.

To sum up so far, then, government research activity in the UK in the 1960s through to the 1990s was large in scale, vibrant, and influential. It was largely self-generated by Home Office researchers rather than imposed on them. It was also often controversial, by no means always

\footnotetext{
${ }^{8}$ Garland (1996) has a useful discussion of how this adaptive strategy of 'responsibilization' took firm hold in UK government policy, influenced by the tenets of SCP.
} 
saying what government would want to hear. SCP was not a government 'sticking plaster', but a new researchinspired way of thinking about reducing crime-one that initially produced a rather sceptical official response, and certainly a negative one from many academics. It has since become entirely accepted. Home Office research on policing was instrumental, and the BCS marked an empirical breakthrough. In the background, as well, was a substantial amount of other research activity, being done in-house or with government support. I contend that this was a good record for administrative criminology.

\section{Changing times}

I move on now to consider how various things changed which in time led to a new wave of hostility towards administrative criminology. This was both in terms of what it was seen as doing, and how it was seen to be doing it.

Politically, with the Conservatives in power since 1979, the Right and Left were outbidding each other to be tough on crime. A new Conservative Home Secretary (Sir Michael Howard) took up the reins in 1992, believing that 'prison works', and not much taken with the research advice he was being given (Windlesham 1996). What was now the Research, Development and Statistics Directorate (RDS) came under threat, and many experienced research staff moved to Universities.

The 1990s, too, saw the emergence of performance management and the setting of a multitude of targets for central and local government agencies relating to crime and criminal justice. [The same trend was evident overseas, but Performance Management in the UK seemed to be particularly vigorous. It was also distinctive in being government-mandated and officially monitored (see Hood 2007)]. One result of Performance Management was that much research capacity was directed towards supplying Performance Indicators to measure progress against targets. The BCS certainly changed as a result, becoming burdened with tracking levels of fear of crime, satisfaction with the police, and confidence in the criminal justice system for instance. This restricted the scope for the survey to pursue new topics and theoretical lines of enquiry as was the case earlier on (see Hough et al. 2007). Crucially, too, RDS came to lose control of the research budget, which had involved it in assessing competing external bids for funds. Instead, control of the research budget was handed out to policy and implementation teams for them to decide how it was to be spent. Tarling (2011) stresses how big a change this was for relationships between administrative criminologists and outside academics, and for the influence that the policy centre had on the nature of research commissioned.

\section{Crime Reduction Programme}

New Labour had come to power in 1997, and liberal criminologists hoped for the best. But Performance Management, if anything, accelerated. Moreover, under a Modernisation programme, civil servants were held accountable for the delivery and outcomes of policies they cared to suggest; and these-critically-were meant to be firmly based on evidence (Wiles 2002). So came about the 1999 Crime Reduction Programme (CRP), described as the most ambitious and innovative programme for tackling crime so far attempted (Homel et al. 2004: v). Based on a stocktake of what we knew about reducing crime (Goldblatt and Lewis 1998) the CRP was given five thrusts; two of these, it can be noted, were geared towards SCP; another was targeted policing. ${ }^{9}$ These are the pointers, the government said: make your bids, but accept stringent evaluation to indicate what offers best value for money. From a large $£ 250 \mathrm{~m}$ budget for the first 3 years, $10 \%$ was earmarked for evaluation, which was largely carried out by a consortia of outside academics (many of them in fact ex-government researchers whom Universities had been happy to employ).

So, the CRP was a golden goose; the country almost literally ran out of criminologists with evaluation skills. Morgan and Hough (2007) judge that some were excited to be part of the exercise, some no doubt simply tempted by what the money meant for them and their employers. The achievements of the CRP, however, are considered dismal (see, e.g., Tonry 2010). What was to be a ten-year initiative was abandoned after three, with relatively few results to show for it. A central point here, though, is that the programme of research left bad feelings on the part of both the evaluators and their paymasters (cf. Newburn 2011). The former resented the heavy hand of the centre, moving goal posts, and apparent massaging of results in summary, low-key publications. (Some outside academics subsequently became wary of accepting government research contracts-although the need to raise money often overcame this.) The Home Office, for its part, felt disappointed by reports with inconclusive results (even if this was due to the fact that few projects were implemented as planned). This tempered faith in universitybased research, starting a trend towards using private

\footnotetext{
${ }^{9}$ Goldblatt and Lewis (1998), drew in part on work recently published by Sherman et al. (1997). One of the two SCP thrusts was tackling high volume crime such as domestic burglary, where a key theme was to develop local infrastructure and skills to identify the nature of different problems. The other was the development of products and systems that are resistant to crime, which went under the 'Foresight' programme. The Goldblatt and Lewis report countered the 'nothing works' mantra as regards penal sanctions and rehabilitative treatment (especially cognitive behaviour therapy); early intervention for young at-risk children was also recommended.
} 
sector consultants and contractors. It has been argued that this development, in the UK and elsewhere, undermined criminology's broader intellectual integrity and academic prestige (Chancer and McLaughlin 2007).

So, is there a defence of administrative criminology at this point? Well, the failure of the CRP, I would argue, was less to do with administrative criminology per se than with endemic problems at the centre and the harsh realities of programme development and rollout. Thus, as Maguire (2004) has documented, there were infeasible timescales, substantial implementation failure, and low commitment to project integrity on the ground. The need for the policy centres to meet the crime reduction targets of the time also meant that this took priority over encouraging and helping administrative criminologists improve the evidence base.

\section{New challenges to administrative criminology}

The demise of the CRP was part of new wave of hostility to administrative criminology. As said, it came to be seen as a type of narrow research done within or for government (or state agencies) within the tight margins of the current political agenda-which was usually felt to be wrong-headed anyway. In 2007, Morgan and Hough characterised the current view of Home Office administrative criminology.

"It is widely contended, and not just by radical outsiders, that most Home Office-funded research is: almost entirely atheoretical fact gathering [...]; narrowly focussed - generally on a recent spending or administrative initiative or piece of legislation; and designed to be, and in its final product invariably is, policy-friendly" (Morgan and Hough 2007: 54).

It is incumbent on me to respond. In relation to fact gathering, I will be robust. In my view, it is entirely defensible to gather facts to judge what is going on and to be able to impart this to others. Moreover, as said, facts are empirical fodder for all criminologists to use as they chose fit. ${ }^{10}$ Has administrative criminology become too narrowly focussed on programme evaluation? That may well be true, although my reckoning is that this is a consequence of increasing managerialism and accountability which cemented the idea that criminology's key role was to produce evidence to underpin the recommendations of policymakers. Moreover, it is arguable that different

\footnotetext{
${ }^{10}$ In The Criminological Imagination, Jock Young (2011) challenged the focus on quantification. He argued for criminology to go back to its creative and critical roots, eschewing quantitative research altogether. He has been widely challenged on this front (e.g., Currie 2012). (There is no reference to administrative criminology in the index to the book, but it would clearly have been in his sights. Victimisation surveys are frequently mentioned).
}

pieces of narrowly focussed work will, with luck, eventually be pulled together to provide more substantial insights. Is administrative criminology designed to be policy friendly (cf. Walters 2007; Hope 2011)? While this is possibly the case, the reality is that research came to be commissioned by those working for political bosses, so it is understandable perhaps if they did not want to challenge too vigorously what their bosses wanted. Certainly, though, the demand for evaluative research to support policy can pose problems for researchers. Those inside government may be able fight their corner a bit better as regards moderating the tone of what is said about results. Generally speaking, those in the Home Office could in the past. Those in universities working under contact might be harder pushed, and fear that shouting too loud will jeopardise future work.

For my own part, I feel that some of the current unease about administrative criminology in the UK is that it has lost some academic weight-though I need to tread carefully here. The loss of control over the research budget may well be one factor-with researchers doing or (increasingly) contracting out work that others see as fitting the bill. However, I would also make the case that in (let us call it) its heyday, administrative criminology was unusually vibrant academically. At that time, researchers were largely operating from within a single professional unit and supported by management which encouraged scholarship (cf. Tarling 2011). After 2004, all Home Office researchers were embedded within policy divisions. ${ }^{11}$ So, the management dynamics may have changed, with more of a focus on simple delivery than on good science, with arguably shorter-term priorities too (cf. Newburn 2011). It is hard to be sure about this, however. The model of criminologists being 'embedded' with practitioners and policy personnel has many supporters (see, e.g., Stanko 2007; Petersilia 2008; Braga and Davis 2014). Moreover, as said, there was some very productive work achieved when some researchers were embedded within the Police Department in the Home Office in the 1980s and 1990s. Laycock and Clarke (2001), in comparing the influence of research on government crime prevention policy in the UK and the US, argue that Home Office research was a good deal more influential than that emanating from NIJ in the US. One reason for this was that NIJ was physically separate from the US Justice Department. This restricted informal contact between research and policy staff and led to NIJ operating in a more passive mode as regards providing information and contributing to knowledge.

\footnotetext{
${ }^{11}$ In 2007, when a Ministry of Justice was hived off from the rest of the Home Office, RDS staff were spilt between the two, but largely remained embedded.
} 


\section{Communication}

A question I believe needs airing is how effectively criminologists put across what they know. This has arisen recently in the debates on both public criminology and translational criminology. Effective communication is a theme in each, and I see a link here with administrative criminology.

There has been much written recently on public criminology-or as it is sometimes rather confusingly called public criminologies (Uggen and Inderbitzin 2010). It was a term adopted in the US by Todd Clear in an address to the 2009 American Society of Criminology (Clear 2010). In the UK, it has been discussed most vocally by Loader and Sparks (2010a). ${ }^{12}$ I have struggled to find a clear, single definition of public criminology, but my interpretation is that it calls for criminologists to upskill in how they deliver and sell their knowledge. This is to both to counteract the apparent declining relevance of criminology, and to put the brakes on bad crime policies. 'Cooling the heat' is how it is put (Loader and Sparks 2010b). More effective communication is one element.

Translational criminology is a term probably best known in the USA. John Laub, a past Director of the National Institute of Justice, adopted translational criminology as his mood music (see Laub 2012), and its home is now the Center for Evidence-Based Crime Policy at George Mason University in Washington. ${ }^{13}$ The principle tenets seem to be: (i) do rigorous research to inform policy (but of different types); (ii) collaborate with practitioners and policy makers to understand how knowledge is translated by them; (iii) go into researcher/practitioner partnerships so that results have better shared ownership; and (iv) develop translation tools for better communication.

In the research environment of the Home Office, great emphasis was placed on the communication of research results. Much store was set by clear elucidation, plain language, contextualising, etc. (I am not saying we always got it right.) Moreover, a basic rule was that policy implications should be clearly spelt out. (In the early days, we sometimes struggled to get funded academics to do this, although over time they learned the ropes.) When much of the crime prevention research moved over to the

\footnotetext{
${ }^{12}$ Loader and Sparks lay out five types of criminological engagement, which they see as 'scientific expert', 'policy advisor,' 'observer turned player,' 'social movement theorist/activist', and 'lonely prophet'. Administrative criminologists would fall most readily into the first two categories, although as a number of reviewers of the book have noted, the five types are not discrete, and one's position can change over time and with circumstance.

13 The Centre was founded in 2008 and has four programmes of work: research on crime and place; evidence-based policing; evidence-based corrections and treatment; and systematic reviews. David Weisburd, Executive Director of the CEBCP, won the Stockholm Prize in Criminology in 2010 for his series of experiments showing that intensified police patrol at high crime 'hot spots' does not merely push crime around the corner.
}

Police Department, Gloria Laycock put even more effort into the mode and manner of publication. She instituted a number of publication series aimed at getting clear messages to the right audiences, which were with deliberately marketed and disseminated to the police through carefully-selected police 'champions.' ${ }^{14}$

It may be harsh to say that most of those outside the administrative criminology stable do less well with communication. But in my view, this is mainly true. They write books to impress each other, which others will often fail to understand. They publish in scholarly journals with limited readership. And they have to abide by academic career structures and incentives that typically do not award points for writing for practitioners or making their voices heard in the policy process (Tonry 2010).

\section{Influence}

If communicating research and knowledge effectively is essential for gaining influence, the question remains of how often is influence achieved. Many refer back to the liberal criminal justice climate of the 1950s and 1960s in the UK (e.g., Faulkner 2010). Then, a small criminological elite had a voice at the policy table, which was largely insulated from the competing influences evident today: electoral politics, ideology, interest groups, the media, and the dreaded public opinion. More pessimistic criminologists now tend to think that it is an unequal battle.

For my purpose, though, the question is whether administrative criminology deserves a more severe reprimand than other forms of criminology with respect to influencing policy. I do not think it does. For one, there are many examples of administrative criminology research that has made a difference. It is telling that Loader and Sparks (2010a: 13), in discussing the influences of research on policy pick as their examples SCP, problem-oriented policing, and preventive interventions focused on risk and protective factors. [This last of course has a broad research base, but it includes the Home Office surveys of youth lifestyles and offending started in 1993 (Graham and Bowling 1995), as well as the

\footnotetext{
${ }^{14}$ The Australian Institute of Criminology (AIC), where I spent time between 2001 and 2003, was unashamedly into communication. A key performance indicator was the number of publications it put out. There was great emphasis on readability, and all publications had prominent press releases. University academics contracted by AIC had to adhere to strict publication 'house rules', and I witnessed some of them finding this difficult. In my view, too, AIC research was lively and had breadth. Whilst I was there, there were reports on illicit markets in diamonds and antiquities; cargo theft; prosecuting serious fraud; and organised crime and people smuggling. Publications in 2015 included: corruption in Australian sport; human trafficking and slavery; offender views on the drop in property crime (offenders cite security, by the way); migrant sex workers; an evaluation of community justice; and 'sexting' among young people. These are topics which I think a wide audience would find interesting.
} 
Cambridge Study of Delinquent Development the beginnings of which were Home Office sponsored]. Moreover, it is hard to deny that the BCS has been a major contributor. Apart from the fact that it now challenges policerecorded crime as the main indicator of crime trends, it was, for instance, a strong driver of policies to improve services for victims, and it identified the important phenomenon of repeat victimisation, the reduction of which became a police performance indicator. It has also served to better quantify the extent of domestic violence, even if there is debate about how accurately it has done so (see Walby et al. 2016 for instance). Second, while the current charge is that administrative criminology is now too narrowly focussed on single, specific initiatives etc., at least the evaluations are being done. They may not make much difference now, but one hopes that they could at least be pulled off the shelf and dusted down at some future point-not least to suggest which policies were most misguided. Finally, as Tonry (2010) has observed, 'windows of opportunity' sometimes open through which new ideas can pass and influence policy shifts. It might be said that SCP benefited from such a window of opportunity, as did research on new methods of policing. Administrative criminologists may be closer to that window.

\section{Concluding remarks}

I have discussed administrative criminology in the UK context, but I feel that those in other countries whose governments conduct and commission research on crime and justice issues and compile statistics on these will recognise it as a genre well enough. I have also discussed administrative criminology in the Home Office from the point of view of its research contribution to-broadlythe crime prevention agenda, which I know best. Other areas of administrative criminology will have made their own contributions, as testified by the Goldblatt and Lewis (1998) stocktake of evidence identifying the most promising avenues of crime control.

In preparing my defence of administrative criminology, I touched base with some ex-colleagues (now in their senior University posts). Some concerns have already been mentioned. I was also told that intellectual collaboration had weakened somewhat, as in-house researchers do less in the way of conducting their own research than simply managing the work of others (although austerity has meant that there is less to be managed). There was some concern about the research procurement process; so too about the handling of research results, which Morgan and Hough (2007) kindly describe as a process of 'traffic calming. My informants seem to have got used to the fact that to pursue any broader-based, thematic ideas of their own they need to look for funds elsewhere than from government. (Fortunately, other sources of funding have emerged, principally from charitable foundations and trusts.) They accept that the Home Office now only calls for research around centrally driven policy concerns. And not least because of funding pressures, many academics in universities and criminological centres are still willing to supply this, and to work co-operatively with in-house researchers. A reflection of this is the recent establishment of the What Works Centre for Crime Reduction, hosted by the College of Policing, which sees researchers both inside government and in contributing together. $^{15}$

So, to conclude, I have defended administrative criminology because I felt it needed someone to stand up for it. I have presented two negative guises of it: one when it was only seen as concerned with SCP; the other more recent one when it was characterised as unimaginative fact-gathering, or narrow, short-termist policy evaluations which needed to come up with acceptable conclusions. I presented my own interpretation of what administrative criminology should be seen as: essentially research specifically geared to serving policy purposes, but which also provides expensive empirical building blocks such as victimisation and offending surveys, as well as "administrative" statistical information on-for instance-what crimes the police know about, who is captured by the criminal justice system and how it deals with them.

I believe that administrative criminology needs to be seen in a positive light. It would be rash to say that all administrative criminology is of a consistently high quality-but there is plenty of quality variation in other modes of criminology too. It is also difficult to contend that administrative criminology has made much headway in quantifying and describing 'big business' fraud, environmental crime, or corporate crime-although very few criminologist working in less of a political straight jacket have done so either. Nonetheless, I see the work done within the Home Office until I retired from it in 2004 as being influential, and I would like to think that the same holds for the output of equivalent research facilities in other countries. I could not see a problem when administrative criminology was associated simply with SCP. This was intellectually grounded, and has become an accepted part of the armoury of measures for reducing crime. (The 'crime drop', no less, has been attributed by some as mainly due to the increase in

\footnotetext{
15 The Centre is co-funded by the Economic and Social Research Centre. It sets out to: (i) review research on practices and interventions to reduce crime; (ii) label the evidence base in terms of quality, cost and impact; and (iii) provide Police and Crime Commissioners and other crime reduction stakeholders with the knowledge, tools and guidance to help them target their resources effectively. The work is being done by the College and a consortium of eight universities, led by University College London.
} 
security that SCP championed-e.g., Farrell et al. 2014). Of course, others are fully within their rights to pursue other avenues for explaining crime and dealing with it. I understand that we are meant to have a balanced portfolio of investments, and it is hard to argue against the case for criminological pluralism and respect for intellectual differences (cf. Currie 2007; Mears 2010). It is also hard to argue that administrative criminology should have to shoulder the burden of developing criminology as an academic discipline.

When administrative criminology became just aligned with doing mainly evaluative research within or for government to their agenda, I did not have much of a problem either. It is entirely reasonable for government to want to know how their policies fare. And even if the evidence governments want is sometimes mis-specified, overly narrow, or not in the end properly heeded (which may be often the case), I do not think that absolves criminologists from trying to speak truth to power. Moreover, one never knows: administrative criminologists working with government may have a more effective voice than those who simply choose to shout at the side lines.

\section{Competing interests}

The authors declare that they have no competing interests.

Received: 12 January 2016 Accepted: 20 April 2016

Published online: 06 May 2016

\section{References}

Braga, A., \& Davis, E. (2014). Implementing science in police agencies: the embedded research model. Policing, 8(4), 294-306.

Brody, S. (1976). The effectiveness of sentencing: a review of the literature. Home Office Research Study No. 35. London: Home Office.

Chancer, L., \& McLaughlin, E. (2007). Public criminologies: diverse perspectives on academia and policy. Theoretical Criminology, 11(2), 155-173.

Clarke, R. V. (1980). Situational crime prevention: theory and practice. British Journal of Criminology, 20, 136-147.

Clarke, R. V. (2005). Seven misconceptions of situational crime prevention. In N. Tilley (Ed.), Handbook of crime prevention and community safety (pp. 39-70). Cullompton: Willan.

Clarke, R. V., \& Hough, M. (Eds.). (1980). The effectiveness of policing. Farnborough: Gower.

Clarke, R. V., \& Hough, M. (1984). Crime and police effectiveness. Home Office Research Study No. 79. London: HMSO.

Clear, T. (2010). Policy and evidence: the challenge to the American society of criminology. 2008 presidential address to the American society of criminology. Criminology, 48, 1-25.

Cornish, D., \& Clarke, R. V. (2003). Opportunities, precipitators and criminal decisions: a reply to Wortley's critique of situational crime prevention. In: M. J. Smith \& D. Cornish (Eds.), Theory for practice in situational crime prevention. Crime Prevention Studies Vol. 16. Monsey: Criminal Justice Press.

Currie, E. (2007). Against marginality: arguments for a public criminology. Theoretical Criminology, 11(2), 175-190.

Currie, E. (2012). Who stole the criminological imagination? contributions to a symposium of reviews of the criminological imagination by Jock Young. British Journal of Criminology, 52, 428-431.

Farrell, G., Tilley, N., \& Tseloni, A. (2014). Why the crime drop. In: M. Tonry (Ed.), Why crime rates fall and why they don't. Crime and Justice Vol. 43. London: University of Chicago Press.
Faulkner, D. (2010). Influences on criminal justice policy, 1959-2009. In: D. Downes, D. Hobbs \& T. Newburn (Eds.), The eternal recurrence of crime and control: essays in honour of paul rock. Oxford: Oxford University Press.

Garland, D. (1996). The limits of the sovereign state: strategies of crime control in contemporary society. British Journal of Criminology, 36(4), 445-471.

Goldblatt, P., \& Lewis, C. (Eds.). (1998). Reducing offending: an assessment of research evidence of ways of dealing with offending behaviour. Home office research study 187. London: Home Office.

Graham, J., \& Bowling, B. (1995). Young people and crime. Home office research study No. 145. London: HMSO.

Hirschi, T. (1993). Administrative Criminology. Contemporary Sociology, 22(3), 348-350.

Homel, P., Nutley, S., Webb, B., \& Tilley, N. (2004). Investing to deliver: reviewing the implementation of the UK crime reduction programme. Home Office Research Study 281. London: Home Office.

Hood, C. (2007). Public service management by numbers. Public Money and Management, 27(2), 95-102.

Hope, T. (2011). Official criminology and the new crime sciences. In M. Bosworth \& C. Hoyle (Eds.), What is criminology?. Oxford: Oxford University Press.

Hough, M. (2014). Confessions of a recovering 'administrative criminologist': jock Young and policy research. Crime, Media, Culture an International Journal, 10(3), 215-226.

Hough, M., \& Maxfield, M. (2007). Surveying crime in the 21st century. Crime Prevention Studies, Vol. 22. Willan Publishing: Cullompton Devon.

Hough, M., Maxfield, M., Morris, B., \& Simmons, J. (2007). The British crime survey after 25 years: progress, problems and prospects. In: M. Hough \& M. Maxfield (Eds.), Surveying crime in the 21st century. Crime prevention studies, Vol. 22. Willan Publishing: Cullompton Devon.

Laub, JH. (2012). Translational criminology. Translational Criminology, Fall: 4-5.

Laycock, G., \& Clarke, R. (2001). Crime prevention policy and government research: a comparison of the United States and United Kingdom. International Journal of Comparative Sociology, XLII(1-2), 235-255.

Liddle, A., \& Gelsthorpe, L. (1994). Crime prevention and inter-agency cooperation. Crime Prevention Unit Papers No. 53. London: Home Office.

Loader, I., \& Sparks, R. (2010a). Public criminology? (key ideas in criminology). Abingdon: Routledge.

Loader, l., \& Sparks, R. (2010b). What is to be done with public criminology? Criminology and Public Policy, 9(4), 725-748.

Maguire, M. (2004). The crime reduction programme in England and Wales: reflections on the vision and the reality. Criminal Justice, 4(3), 213-237.

Martinson, R. (1974). What works? Questions and answers about prison reform. The Public Interest, 35, 22-54.

Matthews, R. (2014). Realist criminology (p. 13). London: Palgrave Macmillan.

Mayhew, P., Clarke, R. V., Hough, M., Sturman, A. (1976). Crime as opportunity. Home Office Research Study No. 34. London: Home Office.

McLaughlin, E. (2006). Administrative criminology. In E. McLaughlin \& J. Muncie (Eds.), The sage dictionary of criminology (2nd ed.). London: Sage.

Mears, D. P. (2010). American criminal justice policy: an evaluation approach to increasing accountability and effectiveness. New York: Cambridge University Press.

Morgan, R., \& Hough, M. (2007). The politics of criminological research. In R. King \& E. Wincup (Eds.), Doing research on crime and justice. Oxford: Oxford University Press.

Newburn, T. (2011). Criminology and government: Some reflections on recent developments in England. In M. Bosworth \& C. Hoyle (Eds.), What is criminology? Oxford: Oxford University Press.

Petersilia, J. (2008). Influencing public policy: an embedded criminologist reflects on California prison reform. Journal of Experimental Criminology, $4(4), 335-356$

Sherman, L., Gottfredson, M., MacKenzie, D., Eck, J., Reuter, P., \& Bushway, S. (1997). Preventing crime: what works, what doesn't, what's promising. for justice programs research report. Washington DC: US Department of Justice.

Stanko, B. A. (2007). From academia to policy making: changing police responses to violence against women. Theoretical Criminology, 11(2), 209-219.

Sutton, M. (1995). Implementing crime prevention schemes in a multi-agency setting: aspects of process in the safer cities programme. Home Office Research Study 160. London: Home Office.

Tarling, R. (2011). Relations between government researchers and academics. Howard Journal of Criminal Justice, 50(3), 307-313. 
Taylor, I., Walton, P. Young, \& Young, J. (1973). The new criminology. London: Routledge.

Tierney, J. (2009). Key perspectives in criminology. Berkshire: Open University Press.

Tilley, N., \& Laycock, G. (2007). From crime prevention to crime science. In G. Farrell, S. Johnson, \& K. Bowers (Eds.), Imagination for crime prevention: essays in honour of ken pease, crime prevention studies (Vol. 21, pp. 19-39). Monsey: Criminal Justice Press.

Tonry, M. (2010). "Public criminology" and evidence-based policy. Criminology and Public Policy, 9(4), 783-797.

Uggen, C., \& Inderbitzen, M. (2010). Public criminologies. Criminology and Public Policy, 9(4), 725-748.

Walby, S., Towers, T., \& Francis, B. (2016). Is violent crime increasing or decreasing? A new methodology to measure repeat attacks making visible the significance of gender and domestic relations. British Journal of Crimino/ogy. http://bjc.oxfordjournals.org/content/early/2016/01/31/bjc.azv131. full.pdf $+h t m l$.
Walters, R. (2007). Embedded criminology. In G. Brannigan \& G. Pavlich (Eds.), Critical studies in social control: the Carson paradigm and governmentality (pp. 309-328). London: Routledge Cavendish.

Wiles, P. (2002). Criminology in the 21 st century: public good or private interest? Australian and New Zealand Journal of Criminology, 35(2), 238-252.

Wilson, J. Q. (1975). Thinking about crime. New York: Basic Books.

Windlesham, L. (1996). Responses to crime (Vol. 3). Oxford: Oxford University Press.

Wortley, R. (2010). Situational crime prevention, critiques of. In B. S. Fisher \& S P. Lab (Eds.), Encyclopaedia of victimology and crime prevention. London: Sage.

Young, J. (1986). The failure of criminology: The need for a radical realism. In R. Matthews \& J. Young (Eds.), Confronting crime. London: Sage.

Young, J. (2011). The criminological imagination. Cambridge: Polity.

\section{Submit your manuscript to a SpringerOpen ${ }^{\circ}$ journal and benefit from:}

- Convenient online submission

- Rigorous peer review

- Immediate publication on acceptance

- Open access: articles freely available online

- High visibility within the field

- Retaining the copyright to your article

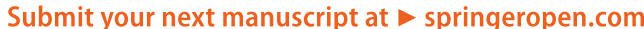

